\title{
DEVELOPMENT OF COMPUTERIZED FERTILIZER RECOMMENDATIONS FOR COCONUT (BASED ON FOLIAR ANALYSIS) USING A LOTUS 123 SOFTWARE PACKAGE SYSTEM
}

\author{
by \\ R.Z. MARGATE, M.I. SECRETARIA, S.S. MAGAT \\ and L.M. ALFORJA ${ }^{1}$
}

\begin{abstract}
A Lotus 123-based system computer program was developed for fertilizer recommendation of local tall verieties and Dwarf x Tall hybrid coconuts using foliar analysis results. The computer program which is coded as PCA-FERT. PRG. Version 1.0 utilized the average fertilizer recommendation formulated by Philippine Coconut Authority based on the Authority's 20 years; of research experience on the nutrition and fertilization of coconut in the country.

As a first attempt towards the computerization of research outputs on coconut nutrition and fertilization, the program, should facilitate the faster assessment of existing coconut stands in terms of its nutritional status and fertilizer needs. The effective utilization of this program coupled with the researcher's knowledge and expertise on the use of foliar analysis results. will contribute much to the formulation of an accurate and reliable fertilizer recommendation.
\end{abstract}

\section{INTRODUCTION}

Leaf or foliar diagnosis as a tool for assessing the fertilizer requirements in plants has been utilized widely due to its several advantages over the other methods i.e. soil analysis, crop deficiency symptoms and field fertilizer experiments. It is more qualitative rather than quantitative in nature, less expensive and provides quicker results. Furthermore, foliar analysis is a more accurate method since it measures the concentration of nutrients actually absorbed by the crop and therefore is not very dependent on varying concepts of soil 'availability' or exchange reactions (Magat, 1988). Since it relates the concentration of leaf nutrients to crop growth and yield, with reference to critical levels of nutrients and consideration on nutrient interaction and 'dilution effect', leaf analysis has been developed successfully as a remedial procedure to correct nutrient deficiency of a crop.

In its applicationto coconut palm, leaf analiysis has been adopted as a diagnostic method largely as a result of the pioneering and successful works of the scientists of the Institut de Recherches pour les Huiles et Oleagineux (IRHO) in West Africa (Child, 1974). In the Philippines, research efforts towards the development of this method to formulate fertilizer recommendation for coconut areas in the country have been initiated in the early 1970's by the Phil. Coconut Research Institute now the Agricultural Research and Development Branch. Works along this line revealed the usefulness of foliar diagnostic technique in predicting the fertilizer requirement of existing coco stands (Magat and Prudente, 1976; Magat, 1976, 1979a, 1979b). In addition to this, further analysis done on soill leaf and yield data of PCA survey data (1975-80) collected from 1,131 sampling areas covering 57 provinces with varying agro-climatic conclitions showed that leaf analysis could give a better predictive value of the nutritional needs of the coconut (Magat, 1988).

Based on 20 years of intensive and extensive research of PCA on coconut nutrition and fertilization in the country and the findings of other countries on the use of foliar analysis for

\footnotetext{
${ }^{1}$ Chief and Science Research Specialist 11, Agronomy \& Soils Division, PCA -Davao Research Center, Bago-Oshiro, Davao City; Manager, Agricultural Research Management Department and Chief, Agric. Research Division, Phil. Coconut Authority, Quezon City.
} 
fertilizer recommendation for coconut, a guide on the suggested nutrient critical levels and the corresponding fertilizer needs based on the average nutrient uptake was developed for tall and Dwarf $\mathrm{x}$ Tall (D x T) hybrid coconuts at different stages of growth. Subsequently, these information were used in the formulation of a fertilizer recommendation for coconut taking into consideration the results of the chemical analysis of the levels of nutrients of a particular leaf reference.

This fertilizer recornmendation for coconut is likely to be used extensively for evaluating the nutritional status of coconut areas considering that about two million out of the 3.4 million hectares of this crop in the Philippines is likely deficient (moderate to strong) in nutrients (Magat and Margate, 1988). Thus, it is expected that a tedious work dealing with voluminous leaf analysis results is on hand. However, with the advent of micro, cornputer facilities in the past decade, this work becomes much easier. In this regard, a Lotus 123-based system computer program was developed to facilitate this job. Hence, this paper covers the procedure for the development of this computer program for fertilizer recornmendation on coconut areas using foliar analysis results.

\section{MATERIALS AND METHODS}

\section{Average Fertilizer Recommendation.}

The average fertilizer recommendation for local tall and dwarf $\mathrm{x}$ tall hybrid coconuts at different stages of growth formulated by PCA was used (Appendix Tables 1-6). This recommendation was based on the integration of results of 20 years of extensive and intensive research on coconut nutrition and fertilization in the country. It utilizes the foliar diagnostic technique which has been adopted since 1970's in the Philippines from IRHO as a tool for predicting the nutritional needs of coconut. Since then, it has been recommended to and used effectively by both small and big coconut farmers and verified by on-farm trials in the country. Hence, this recommendation made use of the following information:

1) Chemical analysis of leaf nutrients (N, P, K, Ca, $\mathrm{Mg}, \mathrm{Cl}$ etc.) and

2) Critical levels of leaf nutrients for local tall variety and $\mathrm{D} x$ Thybrid coconut. These levels are, presented in Appendix Tables 7 and 8 for tall and hybrid coconuts respectively as cited by Magat (1988) from the results of piloting of foreign hybrids in the country from 1977-87. Magat et al (1988) presented in details the methods of estimating these levels for different leaf nutrients for this kind of hybrid.

In the formulation of this fertilizer recommendation, the use of critical level of leaf nutrient played an important role. By comparing the leaf analysis results with the suggested critical levels (Appendix Tables 7 and 8) the deficient elements could be easily identified. Hence, elements whose concentrations are equal or below the critical. levels are supplied in the soil. Likewise, elements whose concentrations are just above the critical levels are also supplied in minimal amount to avert future occurrence of deficiency of such element. Tbus, zero amount of fertilizer source indicates that level of leaf nutrient is much above the critical level and needs no fertilization. While a rate of fertilizer source higher than zero indicates level of nutrient to be a little above, just equal or below the critical, level and therefore needs additional supply of that nutrients in the soil.

\section{Development of a computer program (coded as PCA-FERT. PRG. VERSION 1.0) for the above fertilizer recommendation.}

A Lotus 123-based system computer program was developed to facilitate fertilizer recommendation work especially when the researcher deals with voluminous sample making use of leaf analysis inputs. The program was developed by: 
1. Using the average fertilizer recommendation for local tall and $\mathrm{D} \times \mathrm{T}$ hybrid at leaf rank numbers 4, 9 and 14 based on foliar analysis (Appendix Tables 1-6). These are set-ups of possible levels of leaf nutrients $(\mathrm{N}, \mathrm{P}, \mathrm{K}, \mathrm{Mg}, \mathrm{Cl}, \mathrm{S}$ and $\mathrm{B})$ and their corresponding fertilizer rates using different fertilizer materials (Appendix Table 9).

2. An input/output (I/O) format (Table 1) for each set-up in 1 was made to input the different nutrient concentrations from a given chemical leaf analysis of sample coconut palms and to output the corresponding fertilizer requirement of the palms in terms of source and rate of fertilizer material.

3. Using some Lotus 123 commands, the program was developed in such a way that by entering the concentration of leaf nutrients in the I/O format, the amount and kind of fertilizers needed by the palms will be autornatically outputted.

\section{Guide in the Use of Computer program for Fertilizer Recommendation for Coconuts.}

1. Invoke the Lotus 123 main program diskette in disk drive A of the computer system.

2. Place the PCA-FERT. PRG. diskette in disk drive B.

3. Retrieve any of the following filenames contained in PCA-FERT.

PRG. corresponding to the variety and leaf rank number that is being considered:

3.1 FLOCAL $14 \mathrm{wkl}$ - filename for local tall, leaf rank no. 14

3.2 FLOCAL 9 wk1. - filename for local tall, leaf rank no. 9

3.3 FLOCAL $4 \mathrm{wkl}$, - filename for local tall, leaf rank no. 4

3.4 FHYB 14 wkl. - filename for D x T hybrid, leaf rank no. 14

3.5 FHYB 9 wkI. - filename for D x T hybrid, leaf rank no. 9

3.6 FHYB 4 wkl. - filename for D x T hybrid - leaf rank no. 4

4. Once a chosen filename is on the computer screen, enter the field information data and the concentration of each leaf nutrient (at the second column of the I/O format) and the fertilizer recommendation will be reflected in the computer screen or in print-out form (follow Lotus 123 printing procedure).

\section{RESULTS AND DISCUSSION}

\section{Input-Output of PCA-FERT. PRG. Version 1.0}

To illustrate the use of PCA-FERT. PRG. Version 1.0, a chemical analysis given below from pre-bearing (5 years old) Laguna palms (leaf rank no. 9) was utilized to determine the fertilizer recommendation for these coconuts.

$$
\begin{array}{llll}
\mathrm{N}=2.00 \% & \mathrm{~K}=1.00 \% & \mathrm{Cl}=0.50 \% & \mathrm{~B}=8 \mathrm{ppm} \\
\mathrm{P}=0.20 \% & \mathrm{Mg}=0.25 \% & \mathrm{~S}=0.15 \% &
\end{array}
$$

By entering these values in the 1/0 format of the PCA-FERT.PRG., the rates of the interim recommended fertilizer materials were automatically given by the computer (Table 1). Comparing the given levels of leaf nutrients with the critical levels (Appendix Table 7) to determine which of the elements are deficient and/or sufficient, the coconut area represented by this sample have palms 
suffering from moderate deficiencies in $\mathrm{N}, \mathrm{K}, \mathrm{Mg}, \mathrm{Cl}, \mathrm{S}$, and $\mathrm{B}$, while above satisfactory level of $\mathrm{P}$. This is reflected in the rate of recommended fertilizers outputted by the computer program package. Since $\mathrm{P}$ is above satisfactory level, fertilization of $\mathrm{P}$ source was no longer required, hence 0 rate for superphosphate. Wbile a certain amount of fertilizer sources for $\mathrm{N}, \mathrm{K}, \mathrm{Mg}, \mathrm{Cl}, \mathrm{S}$ and $\mathrm{B}$ were, recommended meaning their levels are below or just within the critical levels and therefore require fertilization.

From Table 1, final selection of appropiate fertilizer sources is made. This is reflected in Table 2. Tlius, for this particular coconut sample palms the appropiate fertilizer recommendations were $0.80 \mathrm{~kg}$ ammonium sulfate, $0.90 \mathrm{~kg}$ potassium chloride, $0.50 \mathrm{~kg}$ dolomite or $0.31 \mathrm{~kg} \mathrm{MgSO}_{4}$ whichever is available and cheaper and $16 \mathrm{~g}$ borax per palm per year. Gypsum was no longer included since the element $\mathrm{S}$ can be provided by ammonium sulfate. Likewise, urea and ammonium chloride are eliminated since, the $\mathrm{N}$ which they contain is already taken cared of by ammonium sulfate. Further, $\mathrm{KCl}$ and $\mathrm{NaCl}$ levels (based on $\mathrm{Cl}$ leaf level) are not considered since the amount of $\mathrm{KCl}$ based on leaf $\mathrm{K}$ is much higher taking care of both $\mathrm{K}$ and $\mathrm{Cl}$.

\section{Points to consider to economize and maximize efficiency of the fertilizer recommendation.}

To assist a researcher in the use of this program for fertilizer recommendation for coconut, there are several points to remember in order to make this methodology an effective tool in diagnosing nutritional needs of coconuts. These are the following:

1. Determine the appropiate fertilizer sources (Appendix Table 9) to supply the deficient elements.

1.1 When double deficiencies occur, use a fertilizer material that will supply both elements. Elements and the respective amounts should be based on the material with a higher fertilizer dosage e.g.

1.1.1 When $\mathrm{K}$ and $\mathrm{Cl}$ are deficient the appropiate fertilizer material to be used is $\mathrm{KCl}$ to supply both elements. In the example (Table 1) based on $\mathrm{K}$ the amount of $\mathrm{KCl}$ is 0.90 $\mathrm{kg} / \mathrm{palm} / \mathrm{yr}$ while based on $\mathrm{C}$ the amount of $\mathrm{KCl}$ is $0.75 \mathrm{~kg} / \mathrm{palm} / \mathrm{yr}$, the preferred dosage is then $0.90 \mathrm{~kg}$.

1.1.2 When $\mathrm{N}$ and $\mathrm{S}$ are, deficient disregard gypsum and use ammonium sulfate to supply $\mathrm{N}$ and $\mathrm{S}$ at the same time.

1.1.3 When $\mathrm{N}$ and $\mathrm{Cl}$ are deficient $\mathrm{KCl}$ and $\mathrm{NaCl}$ may not be used as sources of $\mathrm{Cl}$ but instead use ammonium chloride to supply both elements.

1.2 When multiple deficiencies occur use the minimum number of fertilizer sources that would maximize the supply of the deficient element with least cost e.g. for $\mathrm{N}, \mathrm{K}, \mathrm{Cl}$ and $\mathrm{S}$ deficiencies - use $\left(\mathrm{NH}_{4}\right){ }_{2} \mathrm{SO}_{4}+\mathrm{KCl}$ or $\mathrm{NH}_{4} \mathrm{Cl}+\mathrm{K}_{2} \mathrm{SO}_{4}$ whichever is cheaper instead of $\mathrm{Urea}+\mathrm{KCl}+\mathrm{CaSO}_{4}$ or $\mathrm{NH}_{4} \mathrm{Cl}+\mathrm{KCl}+\mathrm{CaSO}_{4}$

1.3 When a deficient element has-more that one possible sources e. g. $\mathrm{Cl}$ (which can be supplied by $\mathrm{KCl}, \mathrm{NaCl}$ or $\mathrm{NH}_{4} \mathrm{Cl}$ choose the fertilizer material that will come out to be cheaper yet containing other elements. In this case, $\mathrm{NaCl}$ is much cheaper than $\mathrm{KCL}$ or $\mathrm{NH}_{4} \mathrm{Cl}$.

2. Substitution - Supposing the recommended fertilizer source is not available in the market or is too expensive, the use of other materials as substitute could be made based on the dosage given by the PCA-FERT. PRG. Version 1.0 using the following computation: 
Amount of Fert.source given by PCA-FERT. PRG. (A) x Nutrient conc.of Fert. source (\%) (A) = A'

$$
\frac{\mathrm{A}^{\prime}}{\text { Nutrient conc. }(\%) \text { of Fert. source (B) }}=\text { Amount of Fert. source (B) }
$$

where :

Fert. source $(\mathrm{A})=$ amount of unavailable fertilizer $(\mathrm{kg})$

Fert. source $(\mathrm{B})=$ amount of fertilizer source, $(\mathrm{kg})$ as substitute

$\mathrm{A}^{\prime}=$ amount of nutrient in fertilizer source $(\mathrm{A})$ in $\mathrm{kg}$

Example: Assuming dolomite $(10 \% \mathrm{Mg})$ is not avAilable and to be substituted by Magnesium sulfate $(16 \% \mathrm{Mg})$ to supply $\mathrm{Mg}$ requirement

$$
\begin{aligned}
& \mathrm{A}^{\prime}=0.50 \mathrm{~kg} \text { dolomite } \times 10 \% \mathrm{Mg}=0.05 \mathrm{~kg} \mathrm{Mg} \\
& \mathrm{B}=\frac{0.05}{16 \%}=0.31 \mathrm{~kg} \mathrm{MgSO} / \mathrm{palm} / \mathrm{yr} \text { is needed to supply } \mathrm{Mg} \text { requirement }
\end{aligned}
$$

3. In interpreting leaf analysis results, the following considerations should be taken (Margate, 1982) :

3.1 Possible 'dilution effect' resulting to lower values (can be used only during ocular inspection of deficiency symptoms).

3.2 Antagonism between K-Mg, K-Ca or S-Cl.

\section{LIMITATIONS OF THE PROGRAM}

Since the development of this computer program for fertilizer recommendation for coconut is the first attempt towards the computerization of research outputs on coconut nutrition and fertilization, a few fertilizer materials were initially included in the program. It can be observed that only one or two or at most three sources of nutrient were considered. This does not mean, however that these are the only sources of nutrient for coconut. Several other fertilizer materials are available in the market to supply the needed nutrients. For instance, nutrient $\mathrm{K}$ can be obtained not only from $\mathrm{KCl}$ but also from $\mathrm{K}_{2} \mathrm{SO}_{4}, 14-14-14$ or $10-5-20$ compound fertilizers. In this regard, efforts to estimate the fertilizer recommendation for coconut using other sources of nutrient not yet considered in this program is a worthwhile undertaking to improve the program.

On the other hand, this computer program package is limited to a certain extent in the sense that it will not give the final fertilizer recommendation. The accuracy and reliability of making an appropiate fertilizer recommendation will largely depend on one's experience and expertise on the use of the foliar analysis results. The researchers' exposure to field fertilizer trials and fertilizer requirement of coconut will greatly affect his choice of the right fertilizer materials to answer the nutritional needs of coconut areas in the Philippines.

The program considered only six macronutrients and one micronutrient for the fertilizer recommendation for coconut. Nutrient deficiency symptoms of these macronutrients are considered major and widespread problems nationwide while Boron deficiency has been observed lately in new 
plantings especially with improved materials or hybrids (Magat and Margate, 1989). Furthermore, about $60 \%$ of the total plantings in the Philippines is deficient in one or two of these macronutrients and these areas fall under 10 distinct coconut nutritional deficiency classes identified by Magat et al (1981). Hence, these are the most important elements to consider in the rehabilitation of coconut plantations in the country.

\section{SUMMARY AND CONCLUSION}

1) The effective use of the average fertilizer recommendation which was formulated based on 20 years research experience in coconut mineral nutrition and the availability of micro computer facilities helped a lot in the development of this program.

2) This computerized program for fertilizer recommendation in coconut using foliar diagnosis technique is an important factor in the rehabilitation of coconut areas in the country. This breakthrough will facilitate faster evaluation of existing coconut stands in terms of their nutritional requirements.

3) The accuracy and reliability of making the best and appropiate fertilizer recommendation for coconut will greatly depend on the working knowledge and expertise of the one using leaf analysis results.

4) Fertilizer recommendation using other fertilizer materials as sources of nutrients should also be formulated for inclusion in this program.

5) As this is the first attempt to computerize fertilizer recommendation, this program package shall be subject to further refinement as more information and experiences are gained in the future. 


\section{LITERATURE CITED}

CHILD, R. 1974. Coconuts. Tropical Agriculture Series. Second Edition. 355 p.

FREMOND, Y., R. ZILLER and M.DE NUCE DE LAMOTHE. 1966. The Coconut Palm. International Potash Institute. Berne, Switzerland. 227 p.

MAGAT, S. S. 1976. Soil and leaf analysis in relation to coconut yield. Phil. Journal of Coconut Studies. 1(2):1-19.

and R. L. PRUDENTE. 1976. Nutritional requirement and fertilization of coconut. Tech. Information No. 2. Agro-Soils Division. PCA Davao Research Center. In Coconut Abstract on Mineral Nutrition, Fertilization and other Agronomic Practices. Compiled by R. Z. Margate and S. S. Magat. 1980. PCA-DRC, DRC, Davao, City.

, 1979a. The use of leaf analysis in the conduct of field fertilizer trials in the Philippines. Phil. Journal of Coc. Studies. 4(1):32-39.

, 1979b. Leaf analysis: A good way to determining needs of coconuts. Greenfieids. 9(1):4-8. In coconut Abstract on Mineral Nutrition, Fertilization \& other Agronomic Practices Compiled by R. Z. Margate and S. S. Magat. 1980. PCA-DRC, Davao City. 41 P.

J. A. HABANA, A.G. ESCOTON, A. D. LABARCON. and L. B. FROILAN. 1981. Mineral nutrition (leaf) survey of coconuts in the Phil. 1. Nutritional deficiency and fertilization. Phil. Coconut Authority. Agric. Research Branch.

1988. Fertilizer recommendation for coconut based on soil and leaf analysis. Paper presented in the UNDP/FAO Working Group Meeting on Coconut Nutritional Deficiency. Improved Coconut Production in Asia and the Pacific. Sept. 28-30, 1988, Davao City. Philippines.

MAGAT, S.S. and R.Z. MARGATE. 1988. Status on the nutritional deficiencies of coconut in the Phil. Paper presented in the UNDP/FAO Working Group Meeting on Coc. Nutrition al Deficiency. Improved Coconut Production in Asia and the Pacific. Sept. 28-30, 1988. Davao City. Phil.

1989. The Nutritional Deficiency and Fertilization of coconut in the Phil. Research and development Tech. Report no. 2. PCA-Diliman, Quezon City, Phil.

and L. M. ALFORJA. 1988. Critical and optimum levels of nutrients in Coconut Leaves. A guide in Foliar Diagnosis. Paper presented in the UNDP/FAO Working Group Meeting on coconut Nutritional Deficiences. Sept. 28-30, 1988. Davao City. Phil.

MARGATE, R. Z. 1982. Approaches and principles in soil fertility and evaluation. A hand-out on Refresher Course for Regional Agronomists and Project Coordinators. Coco. Ext. Training Center. Bago Oshiro, Davao City, Nov. 22-Dec. 3, 1982. 


\title{
Philippine Coconut Authority \\ Diliman, Quezon City, Tel \# 99-45-01 to 09
}

TABLE 1.

\section{INTERIM FERTILIZER RECOMMENDATION BASED ON LEAF NUTRIENT CONCENTRATIONS*}

\author{
PHI NO. \\ Location : : Sta. Cruz, Davao del Sur \\ Date Sampled : 30 August 1990 \\ Name of Farmer : Juan dela Cruz
}
Leaf Rank No. 9
Local Variety : Laguna
Age of Palms : 5 years
Other info
Reference

\begin{tabular}{|c|c|c|c|c|}
\hline \multirow{2}{*}{$\begin{array}{c}\text { (\%) LEAF } \\
\text { NUTRIENT }\end{array}$} & \multirow{2}{*}{$\begin{array}{c}\text { NUTRIENT } \\
\text { CONCENTRATION }\end{array}$} & \multicolumn{3}{|c|}{ FERTILIZER ** } \\
\hline & & Source & Rate & Unit \\
\hline \multirow[t]{3}{*}{$\% \mathrm{~N}$} & 2.00 & $\left(\mathrm{NH}_{4}\right)_{2} \mathrm{SO}_{4}$ or & 0.80 & $\mathrm{~kg} / \mathrm{palm} / \mathrm{yr}$ \\
\hline & & UREA or & 0.35 & $\mathrm{~kg} /$ palm $/ \mathrm{yr}$ \\
\hline & & $\mathrm{NH}_{4} \mathrm{Cl}$ & 0.67 & $\mathrm{~kg} / \mathrm{palm} / \mathrm{yr}$ \\
\hline$\% \mathrm{P}$ & 0.20 & SP & 0.00 & $\mathrm{~kg} / \mathrm{palm} / \mathrm{yr}$ \\
\hline$\% \mathrm{~K}$ & 1.00 & $\mathrm{KCl}$ & 0.90 & $\mathrm{~kg} / \mathrm{palm} / \mathrm{yr}$ \\
\hline \multirow[t]{2}{*}{$\% \mathrm{Mg}$} & 0.25 & $\mathrm{CaMgCO}_{3}$ or & 0.50 & $\mathrm{~kg} / \mathrm{palm} / \mathrm{yr}$ \\
\hline & & $\mathrm{MGSO}_{4}$ & 0.31 & $\mathrm{~kg} / \mathrm{palm} / \mathrm{yr}$ \\
\hline \multirow[t]{2}{*}{$\% \mathrm{Cl}$} & 0.50 & $\mathrm{KCl}$ or & 0.75 & $\mathrm{~kg} / \mathrm{palm} / \mathrm{yr}$ \\
\hline & & $\mathrm{NaCl}$ & 0.66 & $\mathrm{~kg} / \mathrm{palm} / \mathrm{yr}$ \\
\hline$\% \mathrm{~S}$ & 0.15 & $\mathrm{CaSO}_{4}$ & 0.75 & $\mathrm{~kg} / \mathrm{palm} / \mathrm{yr}$ \\
\hline $\mathrm{B}(\mathrm{ppm})$ & 8 & Borax & 16 & $\mathrm{~g} / \mathrm{palm} / \mathrm{yr}$ \\
\hline
\end{tabular}

PREPARED BY:

Name and Signature

Date

\footnotetext{
** $\left(\mathrm{NH}_{4}\right)_{2} \mathrm{SO}_{4}-$ Ammonium Sulfate $(21 \% \mathrm{~N}, 24 \% \mathrm{~S})$

UREA - $(45 \% \mathrm{~N})$

$\mathrm{NH}_{4} \mathrm{Cl}$ - Ammonium Chloride $(25 \% \mathrm{~N}, 60 \% \mathrm{Cl})$

$\mathrm{CaMgCO}_{3}-(10 \% \mathrm{Mg})$

SP - Super Phosphate (20\% P)

KCI - Potassium Chloride (50\% K, 44\% Cl)

$\mathrm{NaCl}$ - Sodium Chloride - Common salt $(50 \% \mathrm{Cl})$

$\mathrm{CaSO}_{4}-(18 \% \mathrm{~S})$

$\mathrm{MgSO}_{4}-$ Magnesium sulfate $(16 \% \mathrm{Mg}, 23 \% \mathrm{~S})$

Borax $-10 \% \mathrm{~B}$

* This program package was developed by the joint efforts of the Agronomy \& Soils Division, Davao Research Center, Bago Oshiro, Davao City and the Agricultural Research Management Department. Philippine Coconut Authority, Diliman, Quezon City.

Permission to use this program should be obtained from the above offices.
}

Table 2. Final Fertilizer Recornmendation for the given example.

\begin{tabular}{|c|l|l|c|l|}
\hline \multirow{2}{*}{$\begin{array}{c}\text { Variety/ } \\
\text { PHI No. }\end{array}$} & \multicolumn{1}{|c|}{$\begin{array}{c}\text { Narne of Farmer/ } \\
\text { Location of Farm }\end{array}$} & \multicolumn{3}{|c|}{ Fertilizer Recommendation } \\
\cline { 3 - 5 } & \multicolumn{1}{|c|}{ Source } & Rate & \multicolumn{1}{c|}{ Unit } \\
\hline Laguna/1188 & Juan dela Cruz/ & $\left(\mathrm{NH}_{4}\right)_{2} \mathrm{SO}_{4}$ & 0.80 & $\mathrm{~kg} / \mathrm{palm} / \mathrm{yr}$ \\
& Sta. Cruz, Davao & $\mathrm{KCl}$ & 0.90 & $\mathrm{~kg} / \mathrm{palm} / \mathrm{yr}$ \\
& del Sur & $\mathrm{CaMgSO}_{4}$ or & 0.50 & $\mathrm{~kg} / \mathrm{palm} / \mathrm{yr}$ \\
& & $\mathrm{MgSO}_{4}$ & 0.30 & $\mathrm{~kg} / \mathrm{palm} / \mathrm{yr}$ \\
& & Borax & 16 & $\mathrm{~g} / \mathrm{palm} / \mathrm{yr}$ \\
\hline
\end{tabular}


Appendix Table 1. Average fertilizer recommendation for local tall coconut palms, leaf rank no. 14.

\begin{tabular}{|c|c|c|c|c|c|c|c|c|c|c|c|c|c|c|c|c|c|c|c|c|c|}
\hline $\mathrm{N}$ & AS & $\mathbf{P}$ & SP & K & $\mathrm{KCl}$ & $\mathrm{Mg}$ & Dol & $\mathrm{Cl}$ & $\mathrm{KCl}$ & $S$ & Gyp & $\mathrm{Mg}$ & $\mathrm{MgSO}_{4}$ & $\mathrm{Cl}$ & $\mathrm{NaCl}$ & Bppm & Borax & $\mathrm{N}$ & UREA & $\mathrm{N}$ & $A C$ \\
\hline 0.10 & 90 & ?ח0 & & 0.05 & & & 1.95 & 0.02 & & 0.02 & & 05 & 1.22 & 0.02 & & 1 & 60 & 0.10 & 0.93 & 0.10 & 1.60 \\
\hline 1.00 & 1.85 & 0.06 & & 0.20 & & & 1.95 & 0.05 & & 0.04 & 2.00 & & & & & 0 & 55 & 1.00 & & 1.00 & 1.55 \\
\hline 1.20 & 1.80 & 0.07 & 1.20 & 0.30 & 2.10 & 0.14 & 1.90 & 0.10 & 2.20 & 0.05 & 1.95 & 0.14 & 1.19 & 0.10 & 1.94 & 7 & 50 & 1.20 & 085 & 1.20 & 1.51 \\
\hline 1.30 & 1.75 & 0.08 & 0.80 & 0.40 & 2.00 & 0.15 & 1.80 & 0.15 & 2.10 & 0.06 & 1.90 & 0.15 & 1.13 & 0.15 & 1.85 & 8 & & 1.30 & 0.80 & 1.30 & 1.47 \\
\hline 1.40 & 1.70 & 0.09 & 0.70 & 0.50 & 1.80 & 0.16 & 1.75 & 0.20 & 1.90 & 0.07 & 1.85 & 0.16 & 1.09 & 0.20 & 1.67 & 9 & 40 & 1.40 & 075 & 1.40 & 1.43 \\
\hline 1.50 & 1.55 & 0.10 & 0.60 & 0.60 & 1.60 & 0.17 & 1.60 & 0.25 & 1.70 & 0.08 & 1.80 & 0.17 & 1.00 & 0.25 & 1.50 & 10 & 35 & 1.50 & 0.70 & 1.50 & 1.30 \\
\hline 1.60 & 1.50 & 0.11 & 0.50 & 0.70 & 1.40 & 0.18 & 1.50 & 0.30 & 1.50 & 0.09 & 1.70 & 0.18 & 0.94 & 0.30 & 1.32 & 11 & 30 & 1.60 & 0.00 & 1.60 & 1.26 \\
\hline 1.70 & 1.45 & 0.12 & 0.00 & 0.80 & 1.20 & 0.19 & 1.40 & 0.35 & 1.30 & 0.10 & 1.60 & 0.19 & 0.87 & 0.35 & 1.14 & 12 & 30 & 1.70 & 0.65 & 1.70 & 1.22 \\
\hline 1.80 & 1.40 & 0.13 & 0.00 & 0.90 & 1.00 & 0.20 & 1.30 & 0.40 & 1.20 & 0.11 & 1.50 & 0.20 & 0.81 & 0.40 & 1.06 & 13 & 0 & 1.80 & 0.60 & 1.80 & 1.18 \\
\hline 1.90 & 1.20 & 0.14 & 0.00 & 1.00 & 0.90 & 0.21 & 1.20 & 0.50 & 1.10 & 0.12 & 1.40 & 0.21 & 0.75 & 0.50 & 0.97 & 14 & & 1.90 & 0.55 & 1.90 & 1.09 \\
\hline 2.00 & 1.00 & 0.15 & 0.00 & 1.10 & 0.80 & 0.22 & 1.00 & 0.60 & 1.00 & 0.13 & 1.30 & 0.22 & 0.63 & 0.60 & 0.88 & 15 & 0 & 2.00 & 0.50 & 2.00 & 1.00 \\
\hline 2.10 & 0.00 & 0.16 & 0.00 & 1.20 & 0.00 & 0.23 & 0.90 & 0.70 & 0.00 & 0.14 & 1.20 & 0.23 & 0.56 & 0.70 & 0.00 & 16 & 0 & 2.10 & 0.00 & 2.10 & 0.00 \\
\hline 2.20 & 0.00 & 0.17 & 0.00 & 1.30 & 0.00 & 0.24 & 0.80 & 0.80 & 0.00 & 0.15 & 1.00 & 0.24 & 0.50 & 0.80 & 0.00 & 17 & 0 & 2.20 & 0.00 & 2.20 & 0.00 \\
\hline 2.30 & 0.00 & 0.18 & 0.00 & 1.40 & 0.00 & 0.25 & 0.60 & 0.90 & 0.00 & 0.16 & 0.75 & 0.25 & 0.38 & 0.90 & 0.00 & 18 & 0 & 2.30 & 0.00 & 2.30 & 0.00 \\
\hline 2.40 & 0.00 & 0.19 & 0.00 & 1.50 & 0.00 & 0.26 & 0.00 & 1.00 & 0.00 & 0.17 & 0.00 & 0.26 & 0.00 & 1.00 & 0.00 & 19 & 0 & 2.40 & 0.00 & 2.40 & 0.00 \\
\hline 2.50 & 0.00 & 0.20 & 0.00 & 1.60 & 0.00 & 0.27 & 0.00 & 1.10 & 0.00 & 0.18 & 0.00 & 0.27 & 0.00 & 1.10 & 0.00 & 20 & 0 & 2.50 & 0.00 & 2.50 & 0.00 \\
\hline
\end{tabular}


Appendix Table 2. Average fertilizer recommendation for local tall coconut palms, leaf rank no. 9.

\begin{tabular}{|c|c|c|c|c|c|c|c|c|c|c|c|c|c|c|c|c|c|c|c|c|c|}
\hline $\mathrm{N}$ & AS & $\mathbf{P}$ & SP & K & $\mathrm{KCl}$ & $\mathrm{Mg}$ & Dol & $\mathrm{Cl}$ & $\mathrm{KCl}$ & S & Gyp & $\mathrm{Mg}$ & $\mathrm{MgSO}_{4}$ & $\mathrm{Cl}$ & $\mathrm{NaCl}$ & Bppm & Borax & $\mathrm{N}$ & UREA & $\mathrm{N}$ & $A C$ \\
\hline 0.10 & 1.40 & ח & .00 & 0,50 & 40 & 0.05 & 1.90 & 0.02 & 1.60 & 0.02 & 1.95 & 0.05 & 110 & 0.02 & 1.41 & 1 & 22 & 0.10 & 0.65 & 0.10 & 1.18 \\
\hline 1.00 & 1.35 & & .95 & & & & & 0.10 & 1.50 & & & & & & & 6 & & 1.00 & & 1.00 & 1.13 \\
\hline 1.20 & 1.30 & OQ & 0.85 & 0.70 & 1.20 & & 1.75 & 0.15 & 1.40 & 0.05 & 1.90 & 0.15 & 1.00 & & & 7 & 18 & 1.20 & 060 & 1.20 & 1.09 \\
\hline 1.30 & 1.25 & & 0.80 & 0.80 & 1.10 & 0.16 & 1.60 & 0.20 & 1.30 & 0.06 & 1.85 & 0.16 & 1.00 & 0.20 & & 8 & & 1.30 & & 1.30 & 1.05 \\
\hline 1.40 & 1.20 & 0.11 & 0.75 & 0.90 & 1.00 & 0.17 & 1.55 & 0.25 & 1.20 & 0.07 & 1.80 & 017 & 0.97 & 0.25 & 1.06 & 9 & 14 & 1.40 & 055 & 1.40 & 1.00 \\
\hline 1.50 & 1.15 & 0.12 & 0.70 & 1.00 & 0.90 & 0.18 & 1.45 & 0.30 & 1.10 & 0.08 & 1.70 & 0.18 & 0.91 & 0.30 & 0.97 & 10 & 12 & 1.50 & 0.50 & 1.50 & 0.96 \\
\hline 1.60 & 1.10 & 0.13 & 0.60 & 1.10 & 0.80 & 0.19 & 1.35 & 0.35 & 1.00 & 0.09 & 1.60 & 0.19 & 0.84 & 0.35 & 0.88 & 11 & 10 & 1.60 & & 1.60 & 0.92 \\
\hline 1.70 & 0.05 & 0.14 & 0.50 & 1.20 & 0.70 & 0.20 & 1.25 & 0.40 & 0.90 & 0.10 & 1.50 & 0.20 & 0.78 & 0.40 & 0.79 & 12 & 0 & 1.70 & 0.45 & 1.70 & 0.88 \\
\hline 1.80 & 1.00 & 0.15 & 0.40 & 1.30 & 0.60 & 0.21 & 1.00 & 0.45 & 0.80 & 0.11 & 1.40 & 0.21 & 0.63 & 0.45 & 0.70 & 13 & 0 & 1.80 & 0.42 & 1.80 & 0.84 \\
\hline 1.90 & 0.95 & 0.16 & 0.30 & 1.40 & 0.50 & 0.22 & 0.90 & 0.50 & 0.75 & 0.12 & 1.30 & 0.22 & 0.56 & 0.50 & 0.66 & 14 & 0 & 1.90 & 0.40 & 1.90 & 0.80 \\
\hline 2.00 & 0.80 & 0.17 & 0.20 & 1.50 & 0.00 & 0.23 & 0.80 & 0.55 & 0.60 & 0.13 & 1.20 & 0.23 & 0.50 & 0.55 & 0.53 & 15 & 0 & 2.00 & 0.35 & 2.00 & 0.67 \\
\hline 2.10 & 0.70 & 0.18 & 0.00 & 1.60 & 0.00 & 0.24 & 0.75 & 0.60 & 0.50 & 0.14 & 1.00 & 0.24 & 0.47 & 0.60 & 0.44 & 16 & 0 & 2.10 & 0.33 & 2.10 & 0.59 \\
\hline 2.20 & 0.00 & 0.19 & 0.00 & 1.70 & 0.00 & 0.25 & 0.50 & 0.65 & 0.40 & 0.15 & 0.75 & 0.25 & & 0.65 & & 17 & 0 & 2.20 & 0.00 & 2.20 & 0.46 \\
\hline 2.30 & 0.00 & 0.20 & 0.00 & 1.80 & 0.00 & 0.26 & 0.00 & 0.70 & 0.30 & 0.16 & 0.00 & 0.26 & 0.00 & 0.70 & 0.26 & 18 & 0 & 2.30 & 0.00 & 2.30 & 0.34 \\
\hline 2.40 & 0.00 & 0.21 & 0.00 & 1.90 & 0.00 & 0.27 & 0.00 & 0.75 & 0.00 & 0.17 & 0.00 & 0.27 & 0.00 & 0.75 & 0.00 & 19 & 0 & 2.40 & 0.00 & 2.40 & 0.00 \\
\hline 2.50 & 0.00 & 0.22 & 0.00 & 2.00 & 0.00 & 0.28 & 0.00 & 0.80 & 0.00 & 0.18 & 0.00 & 0.28 & 0.00 & 0.80 & 0.00 & 20 & 0 & 2.50 & 0.00 & 2.50 & 0.00 \\
\hline
\end{tabular}


Appendix Table 3. Average fertilizer recommendation for local tall coconut palms, leaf rank no. 4.

\begin{tabular}{|c|c|c|c|c|c|c|c|c|c|c|c|c|c|c|c|c|c|c|c|c|c|}
\hline $\mathrm{N}$ & AS & $\mathbf{P}$ & SP & K & $\mathrm{KCl}$ & $\mathrm{Mg}$ & Dol & $\mathrm{Cl}$ & $\mathrm{KCl}$ & $S$ & Gyp & $\mathrm{Mg}$ & $\mathrm{MgSO}_{4}$ & $\mathrm{Cl}$ & $\mathrm{NaCl}$ & Bppm & Borax & $\mathrm{N}$ & UREA & $\mathrm{N}$ & $A C$ \\
\hline 0.10 & 00 & & 75 & & & & & 0.05 & .10 & 0.02 & & & 0.69 & 0.05 & & 2 & 14 & 0.10 & 45 & 0.10 & 1.84 \\
\hline 1.30 & 0.95 & 0.06 & 0.60 & 0.90 & 1.00 & 0.15 & 1.10 & 0.10 & 1.10 & 0.07 & 1.25 & 0.15 & 060 & 0.10 & 0.97 & 7 & 13 & 1.30 & 0.42 & 1.30 & 0.80 \\
\hline 1.40 & 0.90 & .07 & 0.50 & 1.10 & 0.90 & 0.16 & 1.00 & 0.20 & 1.00 & 0.08 & 1.15 & 0.16 & 0.63 & 0.20 & 0.88 & 8 & 12 & 1.40 & 0.40 & 1.40 & 0.76 \\
\hline 1.50 & 0.85 & 0.08 & 0.40 & 1.20 & 0.80 & 0.17 & 0.90 & 0.30 & 0.90 & 0.09 & 1.05 & 0.17 & 0.56 & 0.30 & 0.79 & 9 & 11 & 1.50 & 0.38 & 1.50 & 0.71 \\
\hline 1.60 & 0.80 & 0.09 & 0.35 & 1.30 & 0.70 & 0.18 & 0.80 & 0.40 & 0.80 & 0.10 & 0.95 & 0.18 & 0.50 & 0.40 & 0.70 & 10 & 10 & 1.60 & 0.35 & 1.60 & 0.67 \\
\hline 1.70 & 0.75 & 0.10 & 0.30 & 1.40 & 0.60 & 0.19 & 0.75 & 0.50 & 0.70 & 0.11 & 0.85 & 0.19 & 0.47 & 0.50 & 0.62 & 11 & 9 & 1.70 & 0.33 & 1.70 & 0.63 \\
\hline 1.80 & 0.70 & 0.11 & 0.25 & 1.50 & 0.50 & 0.20 & 0.70 & 0.60 & 0.65 & 0.12 & 0.75 & 0.20 & 0.44 & 0.60 & 0.57 & 12 & 8 & 1.80 & 0.30 & 1.80 & 0.59 \\
\hline 1.90 & 0.65 & 0.12 & 0.20 & 1.60 & 0.40 & 0.21 & 0.65 & 0.70 & 0.60 & 0.13 & 0.70 & 0.21 & 0.41 & 0.7 & 0.53 & 13 & 7 & 1.90 & 0.28 & 1.90 & 0.55 \\
\hline 2.00 & 0.60 & 0.13 & 0.15 & 1.70 & 0.30 & 0.22 & 0.55 & 0.80 & 0.55 & 0.14 & 0.65 & 0.22 & 0.34 & 0.80 & 0.48 & 14 & 0 & 2.00 & 0.26 & 2.00 & 0.50 \\
\hline 2.10 & 0.55 & 0.14 & 0.10 & 1.80 & 0.20 & 0.23 & 0.50 & 0.90 & 0.50 & 0.15 & 0.60 & 0.23 & 0.31 & 0.90 & 0.38 & 15 & 0 & 2.10 & 0.24 & 2.10 & 0.46 \\
\hline 2.20 & 0.45 & 0.15 & 0.00 & 1.90 & 0.10 & 0.24 & 0.00 & 1.00 & 0.45 & 0.16 & 0.50 & 0.24 & 0.00 & 1.00 & 0.34 & 16 & 0 & 2.20 & 0.22 & 2.20 & 0.38 \\
\hline 2.30 & 0.35 & 0.16 & 0.00 & 2.00 & 0.00 & 0.25 & 0.00 & 1.10 & 0.40 & 0.17 & 0.40 & 0.25 & 0.00 & 1.10 & 0.30 & 17 & 0 & 2.30 & 0.20 & 2.30 & 0.29 \\
\hline 2.40 & 0.20 & 0.17 & 0.00 & 2.10 & 0.00 & 0.26 & 0.00 & 1.20 & 0.35 & 0.18 & 0.30 & 0.26 & 0.00 & 1.20 & 0.25 & 18 & 0 & 2.40 & 0.18 & 2.40 & 0.17 \\
\hline 2.50 & 0.00 & 0.18 & 0.00 & 2.20 & 0.00 & 0.7 & 0.00 & 1.30 & 0.00 & 0.19 & 0.20 & 0.7 & 0.00 & 1.30 & 0.00 & 19 & 0 & 2.50 & 0.00 & 2.50 & 0.00 \\
\hline 2.60 & 0.00 & 0.19 & 0.00 & 2.30 & 0.00 & 0.28 & 0.00 & 1.40 & 0.00 & 0.20 & 0.00 & 0.28 & 0.00 & 1.40 & 0.00 & 20 & 0 & 0.26 & 0.00 & 2.26 & 0.00 \\
\hline 2.70 & 0.00 & 0.20 & 0.00 & 2.40 & 0.00 & 0.9 & 0.00 & 1.50 & 0.00 & 0.21 & 0.00 & 0.9 & 0.00 & 1.50 & 0.00 & 21 & 0 & 0.27 & 0.00 & 2.27 & 0.00 \\
\hline
\end{tabular}


Appendix Table 4. Average fertilizer recommendation for Dwarf $x$ Tall hybrid coconut palms, leaf rank no. 14.

\begin{tabular}{|c|c|c|c|c|c|c|c|c|c|c|c|c|c|c|c|c|c|c|c|c|c|}
\hline $\mathrm{N}$ & AS & $\mathbf{P}$ & SP & K & $\mathrm{KCl}$ & Mg & Dol & $\mathrm{Cl}$ & $\mathrm{KCl}$ & $\mathbf{S}$ & Gyp & Mg & $\mathrm{MgSO}_{4}$ & $\mathrm{Cl}$ & $\mathrm{NaCl}$ & Bppm & Borax & $\mathrm{N}$ & UREA & $\mathrm{N}$ & $A C$ \\
\hline 0.30 & 00 & & & & & & & 0.02 & & & & & & & & & 65 & 0.05 & & 05 & .68 \\
\hline 1.00 & 1.90 & & 1.60 & 0.20 & 210 & 0.16 & 2.00 & 0.10 & 3.00 & 0 & 2.20 & 010 & & 0.15 & & & 60 & 1.00 & 1.00 & 1.00 & 1.60 \\
\hline 1.20 & 1.85 & 06 & .55 & 0.30 & & & & 0.15 & 2.75 & & & & & & & & & 1.20 & & 1.20 & 1.55 \\
\hline 1.30 & 1.80 & 0.07 & 1.50 & 0.40 & 2.15 & 0.18 & 1.50 & 0.20 & 2.50 & 0.06 & 2.10 & 0.18 & 0 & 0.25 & 2.20 & & 50 & 1.30 & 120 & 1.30 & 1.51 \\
\hline 1.40 & 1.75 & .08 & 1.40 & 0.50 & 2.05 & 0.19 & 1.40 & 0.25 & 2.25 & 0.07 & 2.00 & 0.19 & 0.88 & 0.30 & 1.98 & 9 & 45 & 1.40 & 1.40 & 1.40 & 1.47 \\
\hline 1.50 & 1.60 & 0.09 & 1.30 & 0.60 & 1.95 & 0.20 & 1.30 & 0.30 & 2.00 & 0.08 & 1.90 & 0.20 & 0.81 & 0.35 & 1.76 & 10 & 40 & 1.50 & 1.50 & 1.50 & 1.34 \\
\hline 1.60 & 1.55 & 0.10 & 1.20 & 0.70 & 1.85 & 0.21 & 1.20 & 0.35 & 1.75 & 0.09 & 1.80 & 0.21 & 0.75 & 0.40 & 1.54 & 11 & 35 & 1.60 & & 1.60 & 1.30 \\
\hline 1.70 & 1.50 & 0.11 & 1.10 & 0.80 & 1.15 & 0.22 & 1.10 & 0.40 & 1.50 & 0.10 & 1.65 & 0.22 & 0.69 & 0.5 & 1.32 & 12 & 0 & 1.70 & 1.10 & 1.70 & 1.26 \\
\hline 1.80 & 1.45 & 0.12 & 1.00 & 0.90 & 1.50 & 0.23 & 1.00 & 0.45 & 1.40 & 0.11 & 1.50 & 0.23 & & 0.60 & & & 0 & 1.80 & & 1.80 & 1.22 \\
\hline 1.90 & 1.40 & 0.13 & 0.75 & 1.00 & 1.25 & 0.24 & 0.80 & 0.50 & 1.30 & 0.12 & 1.40 & 0.24 & 0.50 & 0.7 & 1.14 & 14 & 0 & 1.90 & 1.90 & 1.90 & 1.18 \\
\hline 2.00 & 1.20 & 0.14 & 0.50 & 1.10 & 1.00 & 0.25 & 0.60 & 0.55 & 1.20 & 0.13 & 1.30 & 0.25 & 0.38 & 0.80 & 1.06 & 15 & 0 & 2.00 & 2.00 & 2.00 & 1.14 \\
\hline 2.10 & 1.00 & 0.15 & 0.00 & 1.20 & 0.50 & 0.26 & 0.50 & 0.60 & 1.00 & 0.14 & 1.20 & 0.26 & 0.31 & 0.90 & 0.88 & 16 & 0 & 2.10 & 2.10 & 2.10 & 1.10 \\
\hline 2.20 & 0.00 & 0.16 & 0.00 & 1.30 & 0.00 & 0.27 & 0.00 & 0.65 & 0.80 & 0.15 & 1.00 & 0.27 & 0.00 & 1.10 & 0.70 & 17 & 0 & 2.20 & & 2.20 & 1.00 \\
\hline 2.30 & 0.00 & 0.17 & 0.00 & 1.40 & 0.00 & 0.28 & 0.00 & 0.70 & 0.70 & 0.16 & 0.80 & 0.28 & 0.00 & 1.20 & 0.62 & 18 & 0 & 2.30 & 2.30 & 2.30 & 0.92 \\
\hline 2.40 & 0.00 & 0.18 & 0.00 & 1.50 & 0.00 & 0.29 & 0.00 & 0.75 & 0.50 & 0.17 & 0.00 & 0.29 & 0.00 & 1.3 & 0.44 & 19 & 0 & 2.40 & & 2.40 & 0.84 \\
\hline 2.50 & 0.00 & 0.19 & 0.00 & 1.60 & 0.00 & 0.30 & 0.00 & 0.80 & 0.00 & 0.18 & 0.00 & 0.30 & 0.00 & 1.40 & 0.00 & 20 & 0 & 2.50 & 2.50 & 2.50 & 0.00 \\
\hline 2.60 & 0.00 & 0.20 & 0.00 & 1.70 & 0.00 & 0.31 & 0.00 & 0.90 & 0.00 & 0.19 & 0.00 & 0.31 & 0.00 & 1.5 & 0.00 & 21 & 0 & 2.60 & 2.60 & 2.60 & 0.00 \\
\hline 2.70 & 0.00 & 0.21 & 0.00 & 1.80 & 0.00 & 0.32 & 0.00 & 1.00 & 0.00 & 0.20 & 0.00 & 0.32 & 0.00 & 1.60 & 0.00 & 22 & 0 & 2.70 & 2.70 & 2.70 & 0.00 \\
\hline
\end{tabular}


Appendix Table 5. Average fertilizer recommendation for Dwarf $x$ Tall hybrid coconut palms, leaf rank no. 9.

\begin{tabular}{|c|c|c|c|c|c|c|c|c|c|c|c|c|c|c|c|c|c|c|c|c|c|}
\hline $\mathrm{N}$ & AS & $\mathbf{P}$ & SP & K & $\mathrm{KCl}$ & $\mathrm{Mg}$ & Dol & $\mathrm{Cl}$ & $\mathrm{KCl}$ & $S$ & Gyp & $\mathrm{Mg}$ & $\mathrm{MgSO}_{4}$ & $\mathrm{Cl}$ & $\mathrm{NaCl}$ & Bppm & Borax & $\mathrm{N}$ & UREA & $N$ & $A C$ \\
\hline 0.25 & .45 & & 50 & & & & & 0.05 & & 02 & 00 & 05 & 22 & & & 2 & 25 & 0.10 & 70 & 0.10 & .22 \\
\hline 1.00 & 1.40 & 0.09 & 1.15 & 0.60 & 1.40 & 0.17 & 1.80 & 0.15 & 1.70 & 0.04 & 2.00 & 0.17 & & 0.15 & & 6 & 23 & 1.00 & 0.68 & 1.00 & 1.18 \\
\hline 1.20 & 1.35 & 0.10 & 1.10 & 0.70 & 1.30 & 0.18 & 1.60 & 0.20 & 1.60 & 0.05 & 1.95 & 0.18 & 10 & 0.20 & & 7 & 21 & 1.20 & 0.65 & 1.20 & 1.13 \\
\hline 1.40 & 1.30 & 0.00 & 1.00 & 0.80 & 1.20 & 0.19 & 1.35 & 0.25 & 1.50 & 0.06 & 1.90 & 0.19 & 0.84 & 0.25 & 1.32 & 8 & 17 & 1.40 & 0.62 & 1.40 & 1.09 \\
\hline 1.50 & 1.25 & 0.12 & 0.90 & 0.90 & 1.10 & 0.20 & 1.80 & 0.30 & 1.40 & 0.07 & 1.85 & 0.20 & 113 & 0.30 & 1.23 & 9 & 15 & 1.50 & 0.60 & 1.50 & 1.05 \\
\hline 1.60 & 1.20 & 0.13 & 0.60 & 1.00 & 1.00 & 0.21 & 1.60 & 0.35 & 1.30 & 0.08 & 1.80 & 0.21 & 1.00 & 0.35 & 1.14 & 10 & 13 & 1.60 & 0.58 & 1.60 & 1.00 \\
\hline 1.70 & 1.10 & 0.14 & 0.40 & 1.10 & 0.90 & 0.22 & 1.50 & 0.40 & 1.25 & 0.09 & 1.70 & 0.22 & 0.94 & 0.40 & 1.10 & 11 & 0 & 1.70 & 0.56 & 1.70 & 0.92 \\
\hline 1.80 & 1.00 & 0.15 & 0.00 & 1.20 & 0.80 & 0.23 & 1.30 & 0.45 & 1.20 & 0.10 & 1.60 & 0.23 & 0.81 & 0.4 & 1.06 & 12 & 0 & 1.80 & 0.54 & 1.80 & 0.84 \\
\hline 1.90 & 0.95 & 0.16 & 0.00 & 1.30 & 0.60 & 0.24 & 1.20 & 0.50 & 1.15 & 0.11 & 1.50 & 0.24 & 0.75 & 0.50 & 1.01 & 13 & 0 & 1.90 & 0.48 & 1.90 & 0.80 \\
\hline 2.00 & 0.90 & 0.17 & 0.00 & 1.40 & 0.00 & 0.25 & 1.10 & 0.55 & 1.10 & 0.12 & 1.40 & 0.25 & 0.69 & 0.55 & 0.97 & 14 & 0 & 2.00 & 0.45 & 2.00 & 0.75 \\
\hline 2.10 & 0.80 & 0.18 & 0.00 & 1.50 & 0.00 & 0.26 & 1.00 & 0.60 & 1.00 & 0.13 & 1.30 & 0.26 & 0.63 & 0.60 & 0.88 & 15 & 0 & 2.10 & 0.40 & 2.10 & 0.67 \\
\hline 2.20 & 0.70 & 0.19 & 0.00 & 1.60 & 0.00 & 0.27 & 0.80 & 0.65 & 0.80 & 0.14 & 1.20 & 0.27 & 0.50 & 0.65 & 0.70 & 16 & 0 & 2.20 & 0.35 & 2.20 & 0.59 \\
\hline 2.30 & 0.00 & 0.20 & 0.00 & 1.70 & 0.00 & 0.28 & 0.75 & 0.70 & 0.50 & 0.15 & 1.00 & 0.28 & 0.47 & 0.70 & 0.44 & 17 & 0 & 2.30 & 0.00 & 2.30 & 0.00 \\
\hline 2.40 & 0.00 & 0.21 & 0.00 & 1.80 & 0.00 & 0.29 & 0.50 & 0.75 & 0.40 & 0.16 & 0.75 & 0.29 & 0.31 & 0.75 & 0.35 & 18 & 0 & 2.40 & 0.00 & 2.40 & 0.00 \\
\hline 2.60 & 0.00 & 0.22 & 0.00 & 1.90 & 0.00 & 0.30 & 0.00 & 0.80 & 0.00 & 0.17 & 0.50 & 0.30 & 0.00 & 0.80 & 0.00 & 19 & 0 & 2.60 & 0.00 & 2.60 & 0.00 \\
\hline 2.80 & 0.00 & 0.23 & 0.00 & 2.00 & 0.00 & 0.31 & 0.00 & 0.90 & 0.00 & 0.18 & 0.00 & 0.31 & 0.00 & 0.90 & 0.00 & 20 & 0 & 2.80 & 0.00 & 2.80 & 0.00 \\
\hline
\end{tabular}


Appendix Table 6. Average fertilizer recommendation for Dwarf x Tall hybrid coconut palm, leaf rank no. 4.

\begin{tabular}{|c|c|c|c|c|c|c|c|c|c|c|c|c|c|c|c|c|c|c|c|c|c|}
\hline $\mathrm{N}$ & AS & $\mathbf{P}$ & SP & $\mathrm{K}$ & $\mathrm{KCl}$ & $\mathrm{Mg}$ & Dol & $\mathrm{Cl}$ & $\mathrm{KCl}$ & $\mathrm{S}$ & Gyp & $\mathrm{Mg}$ & $\mathrm{MgSO}_{4}$ & $\mathrm{Cl}$ & $\mathrm{NaCl}$ & Bppm & Borax & $\mathbf{N}$ & UREA & $\mathbf{N}$ & $A C$ \\
\hline 0.10 & 1.05 & 0.02 & 1.10 & 0.10 & 1.30 & 0.05 & 1.20 & 0.05 & 1.20 & 0.02 & 1.50 & 0.05 & 0.75 & 0.05 & 1.06 & 2 & 16 & 0.10 & 0.48 & 0.10 & 0.88 \\
\hline 1.40 & 1.00 & 0.07 & 1.10 & 1.00 & 1.20 & 0.18 & 1.20 & 0.30 & 1.20 & 0.08 & 1.50 & 0.18 & 0.75 & 0.30 & 1.06 & 7 & 15 & 1.40 & 0.45 & 1.40 & 0.84 \\
\hline 1.50 & 0.95 & 0.08 & 1.00 & 1.10 & 1.10 & 0.19 & 1.100 & 0.35 & 1.10 & 0.09 & 1.35 & 0.19 & 0.69 & 0.35 & 0.97 & 8 & 14 & 1.50 & 0.42 & 1.50 & 0.80 \\
\hline 1.60 & 0.90 & 0.09 & 0.90 & 1.20 & 1.00 & 0.20 & 1.00 & 0.40 & 1.00 & 0.10 & 1.25 & 0.20 & 0.63 & 0.40 & 0.88 & 9 & 13 & 1.60 & 0.40 & 1.60 & 0.76 \\
\hline 1.70 & 0.85 & 0.10 & 0.80 & 1.30 & 0.90 & 0.21 & 0.90 & 0.45 & 0.90 & 0.11 & 1.15 & 0.21 & 0.56 & 0.45 & 0.79 & 10 & 12 & 1.70 & 0.38 & 1.70 & 0.71 \\
\hline 1.80 & 0.80 & 0.11 & 0.70 & 1.40 & 0.80 & 0.22 & 0.80 & 0.50 & 0.80 & 0.12 & 1.05 & 0.22 & 0.50 & 0.50 & 0.70 & 11 & 11 & 1.80 & 0.36 & 1.80 & 0.67 \\
\hline 1.90 & 0.70 & 0.12 & 0.60 & 1.50 & 0.70 & 0.23 & 0.75 & 0.55 & 0.70 & 0.13 & 0.95 & 0.23 & 0.47 & 0.55 & 0.62 & 12 & 10 & 1.90 & 0.34 & 1.90 & 0.59 \\
\hline 2.00 & 0.75 & 0.13 & 0.50 & 1.60 & 0.60 & 0.24 & 0.70 & 0.60 & 0.65 & 0.14 & 0.85 & 0.24 & 0.44 & 0.60 & 0.57 & 13 & 9 & 2.00 & 0.32 & 2.00 & 0.55 \\
\hline 2.10 & 0.60 & 0.14 & 0.30 & 1.70 & 0.50 & 0.25 & 0.65 & 0.65 & 0.60 & 0.15 & 0.75 & 0.25 & 0.41 & 0.65 & 0.53 & 14 & 0 & 2.10 & 0.30 & 2.10 & 0.50 \\
\hline 2.20 & 0.00 & 0.15 & 0.00 & 1.80 & 0.40 & 0.26 & 0.60 & 0.70 & 0.55 & 0.16 & 0.70 & 0.26 & 0.38 & 0.70 & 0.48 & 15 & 0 & 2.20 & 0.00 & 2.20 & 0.42 \\
\hline 2.30 & 0.00 & 0.16 & 0.00 & 1.90 & 0.30 & 0.27 & 0.55 & 0.75 & 0.00 & 0.17 & 0.65 & 0.27 & 0.34 & 0.75 & 0.00 & 16 & 0 & 2.30 & 0.00 & 2.30 & 0.00 \\
\hline 2.40 & 0.00 & 0.17 & 0.00 & 2.00 & 0.00 & 0.28 & 0.50 & 0.80 & 0.00 & 0.18 & 0.60 & 0.28 & 0.31 & 0.80 & 0.00 & 17 & 0 & 2.40 & 0.00 & 2.40 & 0.00 \\
\hline 2.50 & 0.00 & 0.18 & 0.00 & 2.10 & 0.00 & 0.29 & 0.00 & 0.85 & 0.00 & 0.19 & 0.50 & 0.29 & 0.00 & 0.85 & 0.00 & 18 & 0 & 2.50 & 0.00 & 2.50 & 0.00 \\
\hline 2.60 & 0.00 & 0.19 & 0.00 & 2.20 & 0.00 & 0.30 & 0.00 & 0.90 & 0.00 & 0.20 & 0.00 & 0.30 & 0.00 & 0.90 & 0.00 & 19 & 0 & 2.60 & 0.00 & 2.60 & 0.00 \\
\hline 2.70 & 0.00 & 0.20 & 0.00 & 2.30 & 0.00 & 0.31 & 0.00 & 0.95 & 0.00 & 0.21 & 0.00 & 0.31 & 0.00 & 0.95 & 0.00 & 20 & 0 & 2.70 & 0.00 & 2.70 & 0.00 \\
\hline
\end{tabular}


Appendix Table 7.

Guide on coconut leaf critical levels (\% of dry matter) for tall (Typica) variety.

\begin{tabular}{|c|c|c|c|c|}
\hline \multirow{2}{*}{$\begin{array}{l}\text { Nutrient/ } \\
\text { Leaf No. }\end{array}$} & \multicolumn{4}{|c|}{ REFERENCE } \\
\hline & IRHO $^{1}$ & UNILEVER $^{2}$ & KANAPATHY $^{3}$ & $\mathbf{P C A}^{4}$ \\
\hline \multicolumn{5}{|l|}{ Macronutrient } \\
\hline \multicolumn{5}{|l|}{ Nitrogen } \\
\hline Leaf 4 & 2.20 & 1.80 & - & - \\
\hline 9 & 2.20 & 1.95 & - & - \\
\hline 14 & $1.80-2.00$ & 2.00 & 1.80 & 0.18 \\
\hline \multicolumn{5}{|l|}{ Phosphorus } \\
\hline Leaf 4 & 0.138 & 0.16 & - & - \\
\hline 9 & 0.130 & 0.15 & - & - \\
\hline 14 & 0.120 & 0.14 & 0.12 & 0.12 \\
\hline \multicolumn{5}{|l|}{ Potassium } \\
\hline Leaf 4 & 1.75 & 1.70 & - & - \\
\hline 9 & 1.15 & 0.30 & - & - \\
\hline 14 & $0.80-1.00$ & 1.00 & $0.80-1.10$ & 0.80 \\
\hline \multicolumn{5}{|l|}{ Calcium } \\
\hline Leaf 4 & - & 0.34 & - & - \\
\hline 9 & - & 0.44 & - & - \\
\hline 14 & 0.50 & 0.55 & $0.15-0.30$ & 0.30 \\
\hline \multicolumn{5}{|l|}{ Magnesium } \\
\hline Leaf 4 & 0.22 & 0.23 & - & - \\
\hline 9 & 0.24 & 0.25 & - & - \\
\hline 14 & $0.24-0.28$ & 0.26 & 0.30 & 0.20 \\
\hline \multicolumn{5}{|l|}{ Sodium } \\
\hline Leaf 4 & - & 0.12 & - & - \\
\hline 9 & - & 0.17 & - & - \\
\hline 14 & 0.40 & 0.20 & - & - \\
\hline \multicolumn{5}{|l|}{ Chlorine } \\
\hline Leaf 4 & - & - & - & $0.40-0.70$ \\
\hline 9 & - & - & - & $0.30-0.55$ \\
\hline 14 & 0.50 & - & - & $0.30-0.40$ \\
\hline \multicolumn{5}{|l|}{ Sulfur } \\
\hline Leaf 4 & - & - & - & - \\
\hline 9 & - & - & - & - \\
\hline 14 & $0.15-0.20$ & - & - & 0.12 \\
\hline \multirow{2}{*}{\multicolumn{5}{|c|}{$\begin{array}{l}\text { Micronustrient } \\
\text { Boron (ppm) }\end{array}$}} \\
\hline & & & & \\
\hline Leaf 4 & - & 13 & - & $9-13$ \\
\hline 9 & - & 14 & - & - \\
\hline 14 & - & 14 & - & $9-11$ \\
\hline
\end{tabular}

1. Fremond et al (1966). The Coconut Palm. Int. Potash Institute, Berne, Switzertand. 227 p.

2. Friend (1975). The Solomon Islands and Levers Pacific Plantations. Prorietory Limited Joint Coc. Research Scheme. 1971-74.

3. Kanapathy (1971). Preliminary work on foliar analysis as a guide to the manuring of coconuts. Conference on Cocoa and coconuts. (Incorporated Society of Planters). Kuala Lumpur, Malaysia.

4. Magat. S. S. (1979). The use of leaf analysis in the conduct of field fertilizer trials in the Phil. Phil. Journal of Coc. Studies. 4 (1):32-39. 
Appendix Table 8.

A guide on coconut leaf nutrient critical levels ( $\%$ of dry matter) for Dwarf $x$ Tall hybrids.

\begin{tabular}{|c|c|c|c|}
\hline \multirow{3}{*}{ Nutrient } & \multicolumn{3}{|c|}{ REFERENCE } \\
\hline & \multicolumn{2}{|c|}{ IRHO $^{1}$} & $\mathrm{CA}^{2}$ \\
\hline & Critical level & Critical level & Optimum level \\
\hline \multicolumn{4}{|l|}{ Nitrogen } \\
\hline Leaf 4 & 2.20 & 1.95 & 2.00 \\
\hline 9 & 2.20 & 1.80 & 2.00 \\
\hline 14 & 2.20 & 1.80 & 2.00 \\
\hline \multicolumn{4}{|l|}{ Phosphorus } \\
\hline Leaf 4 & 0.14 & 0.13 & 0.15 \\
\hline 9 & 0.13 & 0.12 & 0.13 \\
\hline 14 & 0.12 & 0.12 & 0.13 \\
\hline \multicolumn{4}{|l|}{ Potassium } \\
\hline Leaf 4 & 2.00 & 1.70 & 1.90 \\
\hline 9 & 1.70 & 1.00 & 0.17 \\
\hline 14 & 1.40 & 0.90 & 1.10 \\
\hline \multicolumn{4}{|l|}{ Calcium } \\
\hline Leaf 4 & - & 0.35 & 0.41 \\
\hline 9 & - & 0.34 & 0.38 \\
\hline 14 & - & 0.32 & 0.35 \\
\hline \multicolumn{4}{|l|}{ Magnesium } \\
\hline Leaf 4 & 0.24 & 0.25 & 0.29 \\
\hline 9 & 0.23 & 0.30 & 0.33 \\
\hline 14 & 0.20 & 0.30 & 0.33 \\
\hline \multicolumn{4}{|l|}{ Sodium } \\
\hline Leaf 4 & - & 0.30 & 0.37 \\
\hline 9 & - & 0.20 & 0.25 \\
\hline 14 & - & 0.15 & 0.17 \\
\hline \multicolumn{4}{|l|}{ Chlorine } \\
\hline Leaf 4 & - & 0.65 & 0.74 \\
\hline 9 & - & 0.55 & 0.60 \\
\hline 14 & - & 0.45 & 0.52 \\
\hline \multicolumn{4}{|l|}{ Sulfur } \\
\hline Leaf 4 & - & 0.17 & 0.19 \\
\hline 9 & - & 0.15 & 0.17 \\
\hline 14 & - & 0.15 & 0.16 \\
\hline
\end{tabular}

1. Manciot et al (1979). Nutrition minerale et fertilization de cocotier dan lemonde (Bilingue fr.-angi.) Olegineux. 34 (11). 499-515.

2. Magat (1988). Fertilizer recommendation for coconuts based on soil and leaf analysis. Paper presented in UNDP/FAO Working Group Meeting on Coconut Nutritional Deficiency. Sept. 28-30, 1988. PCA-DRC, Davao City, Phil. 
Appendix Table 9. Fertilizer materials used as sources of nutrients.

\begin{tabular}{|c|c|c|c|}
\hline $\begin{array}{c}\text { LEAF } \\
\text { NUTRIENT }\end{array}$ & $\begin{array}{l}\text { FERTILIZER } \\
\text { SOURCE }\end{array}$ & $\begin{array}{c}\text { FERTILIZER } \\
\text { GRADE }\end{array}$ & $\begin{array}{l}\text { NUTRIENT CONC. } \\
\text { OF FERTILIZER }\end{array}$ \\
\hline \multirow[t]{3}{*}{$\mathrm{N}$} & Ammonium sulfate & $21-0-0-24$ & $21 \% \mathrm{~N}, 24 \% \mathrm{~S}$ \\
\hline & UREA & $45-0-0$ & $45 \% \mathrm{~N}$ \\
\hline & Ammonium chloride & $25-0-0-60$ & $25 \% \mathrm{~N}, 60 \% \mathrm{Cl}$ \\
\hline$P$ & Superphosphate & $0-20-0$ & $20 \% \mathrm{P}$ \\
\hline K & Potassium chloride & $0-0-60-44$ & $50 \% \mathrm{~K}, 44 \% \mathrm{Cl}$ \\
\hline \multirow[t]{2}{*}{$\mathrm{Mg}$} & Magnesium sulfate & $\mathrm{MgSO}_{4} \cdot \mathrm{nH}_{2} \mathrm{O}$ & $16 \% \mathrm{Mg}, 23 \% \mathrm{~S}$ \\
\hline & Dolomite & $\mathrm{CaMgCO}_{3}$ & $10 \% \mathrm{Mg}$ \\
\hline \multirow[t]{3}{*}{$\mathrm{Cl}$} & Potassium chloride & $0-0-60-44$ & $50 \% \mathrm{~K}, 44 \% \mathrm{Cl}$ \\
\hline & Sodium chloride & $0-0-0-50$ & $50 \% \mathrm{Cl}$ \\
\hline & Ammonium chloride & $25-0-0-60$ & $60 \% \mathrm{Cl}$ \\
\hline S & Gypsum & $\mathrm{CaSO}_{4} \cdot \mathrm{nH}_{2} \mathrm{O}$ & $23 \% \mathrm{Ca}, 18 \% \mathrm{~S}$ \\
\hline B & Borax & $\mathrm{Na} 2 \mathrm{~B} 407 . \mathrm{nH}_{2} \mathrm{O}$ & $10 \% \mathrm{~B}$ \\
\hline
\end{tabular}

